Aletria, Belo Horizonte, v. 31, n. 3, p. 55-74, 2021

(c) (1)

\title{
Trânsfugas e outros herdeiros das cinzas em Milton Hatoum
}

\author{
Defectors and Other Heirs of Ashes in Milton Hatoum
}

\author{
Luciana Persice Nogueira-Pretti \\ Universidade do Estado do Rio de Janeiro (UERJ), Rio de Janeiro, Rio de Janeiro / Brasil \\ luciana.persice@yahoo.com.br
}

http://orcid.org/0000-0003-4374-5347

Resumo: A figura do trânsfuga, conceituada aqui a partir de aportes de Pierre Bourdieu (2007) e Martine Leibovici (2014), tem uma presença marcante na obra literária de Milton Hatoum. Em seus três primeiros romances, que se sucedem e possuem elementos de continuidade de um a outro, observaremos alguns personagens, inclusive os narradores, como essa figura que transita entre dramas existenciais cruciais, tais como orfandade, bastardia, linhagem familiar, e diversas formas de estraneidade - seja enquanto estrangeiro em terra de acolhimento, um "estranho no ninho" da família onde nasce ou é acolhido, ou ainda noutras formas de interagir no mundo e com o Outro. Seres em trânsito ou fuga, alguns dos personagens de Hatoum nos permitem, então, evidenciar o estranhamento, a estranheza e inadequação no interior da própria casa, que às vezes é espelho de nosso país, e observar como eles encontram, cada qual à sua maneira, formas inesperadas de seguir caminho.

Palavras-chave: Milton Hatoum; trânsfugas; estraneidade.

Abstract: The figure of the defector, conceptualized here based on works by Pierre Bourdieu (2007) and Martine Leibovici (2014), has a strong presence in the literary work of Milton Hatoum. In his first three novels, written in a sequence, with elements of continuity from one to another, we will observe a few characters, including the narrators, as this figure who transits between crucial existential dramas, such as orphanhood, bastardy, family lineage, and several forms of strangeness - whether as a foreigner in a host country, a "stranger in the nest" of the family where he or she is born or welcomed, or in other ways of interacting in the world and with the Other. Beings in transit or flight, some of Hatoum's characters then allow us to show the strangeness, the oddity and the inadequacy inside the house itself, which is sometimes a mirror of our country, and to observe how they encounter, each in their own unexpected way of moving on.

Keywords: Milton Hatoum; defector; strangeness.

eISSN: 2317-2096

DOI: $10.35699 / 2317-2096.2021 .24176$ 
Em seu estudo sobre "As contradições da herança", Pierre Bourdieu analisa a "questão absolutamente fundamental em toda sociedade que é a ordem das sucessões, ou seja a relação da gestão das relações entre pais e filhos e, mais precisamente, da perpetuação da linhagem" ou a "tendência a perseverar no ser" (BOURDIEU, 2007, p. 231), que se traduz pela transmissão da herança paterna, suas condições e condicionamentos. É com relação a essa transmissão e eventual perpetuação que o sociólogo se refere aos "trânsfugas", ou, mais precisamente, aos "trânsfugas de classe". Nesse contexto, o trânsfuga seria o filho que lida com a experiência do "dilaceramento" ante a tarefa atribuída pelo pai de superá-lo em termos socio-econômicos. Bourdieu cita, em nota, o exemplo do jovem francês de origem árabe, "imprensado entre dois universos inconciliáveis" e que deve procurar "pais adotivos" nas figuras dos pais da namorada ("franco-francesa"), e, "através dela, a possibilidade de se reconhecer na escola" (BOURDIEU, 2007, p. 235). Entre fenômenos da sociologia e da psicologia, o trânsfuga escapa à identificação total com a classe social de origem (nesse caso, os pais pobres e/ou estrangeiros) e a de destino (o meio a que tem acesso eventual por casamento e/ou escolarização e educação).

O tema do trânsfuga, social ou não, se encontra e se multiplica no âmago da literatura de Milton Hatoum, e seus romances, pelo menos os três primeiros - que constituem o corpus desse trabalho -, versam sobre variações de contradições e contraditores da herança e da linhagem, seus heróis sendo transeuntes no espaço incerto e movediço do entredois mundos: o país de origem e o país de destino, a situação familiar inicial e o projeto de vida futura (seja em termos de ascensão social, de independência econômica, ou de simples distanciamento físico), ou a identidade individual no interior do núcleo familiar e as possibilidades e perspectivas de uma nova identidade (ou identificação) fora desse núcleo.

Pretendemos caracterizar aqui alguns dos trânsfugas em três romances que se sucedem: Relato de um certo Oriente (1989), Dois irmãos (2000) e Cinzas do Norte (2005); personagens trágicos que encenam diferentes histórias de estraneidade e estranhamento; personagens ou seres ambíguos que conversam com elementos autobiográficos do autor, mas também com o espaço amazônico e sua capital, de fulgurante e paradoxal cosmopolitismo ilhado, eivada da memória de migrações e da imigração; seres híbridos que dialogam com o drama do "perseverar no ser" e no estar com o Outro, na relação assimétrica e dialética entre identidade e alteridade, e entre inclusão e exclusão.

Os três romances possuem em comum, de pronto, uma mesma forma de estruturação: em entrevista, Hatoum revela que, nos três casos, escreveu "o início, o fim e, só depois, o resto" (MILTON, 2009) - como 
bom leitor de Proust. Deixou-se extraviar pelas contingências da trama, pelos vãos e desvãos da memória num vaivém incessante entre diferentes tempos e espaços, mas levou seu leitor ao final projetado - que nem é feliz nem conclusivo, deixando um rastro de mistérios, lacunas, alusões e perplexidades à deriva da leitura; leitor que se compadece do fado do(s) herói(s) e se depara com a obra aberta, que exige reflexão, a ser desvendada, de preferência relida - uma vez que, retrospectivamente, vários diálogos ou informações parciais fornecidas pelos narradores adquirem novo sentido diante de revelações subsequentes; leitor que, ao longo da leitura, foi implicitamente ou explicitamente - sensibilizado às artimanhas do processo da criação artística, pois esses romances são, também, meta-literários.

Com relação à figura do trânsfuga e suas várias ocorrências no texto de Hatoum, vale lembrar que se trata de um conceito inicialmente do âmbito da sociologia (da cultura) mas que, mais recentemente, tem sido estudado pelo viés da filosofia política: Martine Leibovici, por exemplo, estuda os trânsfugas sob essa perspectiva, priorizando narrativas autobiográficas. E seu estudo nos lembra que, nesse caso, quando o narrador

é um trânsfuga, que viveu ou ainda vive a repetição de situações em que se sentiu "pisando em falso" 1 - de certa forma aspirando a um alhures ou de certa forma provindo de um alhures - seu desejo de escritura excede o simples desejo de compreensão e exposição de si: ele também escreve para dar sentido à defasagem constantemente revivida entre suas disposições pessoais e a configuração das relações sociais em que ele teve que evoluir e que seu texto decifra. (LEIBOVICI, 2014, p.112, tradução nossa) ${ }^{2}$

Nos romances de Hatoum (que não são autobiográficos nem autoficcionais), narradores e/ou protagonistas compartilham a marca do imigrante, carregada pelo autor: nascido numa família de origem estrangeira, ele partiu de Manaus ainda muito jovem e foi para "o Sul": Brasília, São Paulo, Europa e alhures. Assim, ele próprio trânsfuga em contexto de imigração, "de certa forma aspirando a ou provindo de um

\footnotetext{
1 No original, "en porte à faux", expressão que pode significar também "em desacordo, contradição ou conflito com", "em desequilíbrio" ou "em situação desconfortável”, numa rica malha semântica.

${ }^{2} \ll$ est un transfuge, ayant vécu ou vivant encore la répétition de situations où il s'est senti en porte-à-faux — étant quelque part en aspirant à un ailleurs ou étant quelque part en venant d'ailleurs - , son désir d'écriture excède le simple désir de compréhension et d'exposition de soi: il écrit aussi pour donner sens à ce décalage constamment revécu entre ses propres dispositions et la configuration des relations sociales où il a eu à évoluer et que son texte décrypte ».
} 
alhures", faz de seus personagens, sobretudo os narradores escritores, seres que buscam essa "compreensão e exposição de si" enquanto tentam "dar sentido à defasagem" entre sua pessoa e seu entorno, entre sua identidade e seu lugar dentro da casa onde são criados; seres que habitam e evoluem nessa defasagem, nesse entre-dois assimétrico e instável; seres que oscilam, entre outros, entre inclusão e exclusão em seu meio - de origem e/ou de destino (LEIBOVICI, 2014). E o migrar do velho ao novo mundo pessoal exige abandonos, perdas e desperdícios; exige a um só tempo largar amarras e queimar navios, e caminhar, traçando e tramando rastros, sobre as cinzas do passado que se rejeita e deserta. É o que pretendemos evidenciar a partir de alguns dos trânsfugas mais marcantes: a narradora inominada e Halim (que também é, em certos momentos, narrador de Relato de um certo Oriente), o narrador Nael e Yaqub (Dois irmãos), e o narrador (e protagonista) Lavo e Mundo (Cinzas do Norte).

\section{Trânsfugas e outros dilacerados}

O dilaceramento de que fala Bourdieu (2007) em seu estudo sobre "as contradições da herança" familiar, refere-se a pais que esperam que os filhos os superem em termos de sucesso econômico e social, e a filhos que vão se esforçar para atenderem a essa expectativa, numa empreitada fadada ao drama: se tiver êxito, o filho se afastará (fisicamente, emocionalmente, ideologicamente, politicamente etc.) de sua origem - o que gera sofrimento; se fracassar, o filho frustrará o projeto da família de progredir ou prosperar (seja em seu conjunto ou nas realizações individuais dos membros) - o que também gera transtorno.

Os narradores e outros personagens de Hatoum são seres dilacerados, cada qual à sua maneira, e se afligem entre êxito e fracasso, realizações e frustrações, sobretudo tendo como referência a família e sua posição em seu núcleo. Todos têm relação complexa com a linhagem e, juntamente com outros personagens, fazem com que a orfandade, a bastardia e a adoção constituam temas privilegiados nos romances.

Por exemplo, a narradora inominada de Relato de um certo Oriente (doravante Relato) e seu irmão de sangue, também não nomeado, são adotados pela matriarca Emilie. Não fica clara a razão dessa adoção, sabese apenas que a mãe biológica é vizinha de Emilie, e que tem contato com 
os filhos quando já adultos (não há qualquer menção ao pai biológico). ${ }^{3}$ Emilie tem quatro filhos com o marido (igualmente sem nome), aos quais a narradora e seu irmão de sangue, muito mais jovens, chamam de "tios". Depois de quase vinte anos de ausência, a narradora retorna a Manaus com o propósito anunciado de reencontrá-la em seu leito de morte, devendo fazer o relato desse reencontro - que não acontece - ao irmão de sangue. A narrativa se estrutura como uma sucessão de narrações, cartas e outros testemunhos encaixados ou encadeados uns aos outros, articulados em torno da história dessa família de imigrantes levantinos e, sobretudo, da figura e da imagem de Emilie. O livro é o relato pedido pelo irmão, que imigrou para a Espanha.

A narradora, então, será adotada por uma família que foi acolhida pelo Brasil, numa mise en abyme $e^{4}$ de adoções; consequentemente, será duplamente estrangeira, pois, de certa forma, será uma "estranha no ninho" nessa casa de imigrantes. Também ela, como o irmão que vive em Barcelona, deixa a terra natal, tornando-se, em novo espelhamento, migrante. Ela parte para “o Sul”, São Paulo, megalópole onde todos são anônimos, "filhos de ninguém", e, talvez por isso mesmo, livres para assumirem novas vidas e identidades, mas onde ela encontra adversidades (não explicadas ao leitor) e passa algum tempo internada numa clínica de repouso. Volta a Manaus (temporariamente) para esse desencontro e esse relato, que termina falando sobre a dificuldade de narrar.

A narradora se instala na casa da mãe biológica (que está ausente, viajando), e já no primeiro diálogo, fragmentário, que tem com a empregada da casa, a questão da filiação desponta, pois ela lhe pergunta "se a criança [ao seu lado] era sua filha ou enteada" (HATOUM, 2008, p. 8) - tema de monta que se anuncia já na segunda página do relato. Ao sair para visitar a mãe adotiva, encontra a casa fechada, então, resolve dar um passeio pela cidade, um percurso nostálgico que é, sobretudo, um "diálogo" mental e afetivo:

3 Pela descrição do interior da casa dessa mãe biológica, também ela sem nome, supõese que ela também seja de origem árabe (uma mistura de tapetes e baús orientais, objetos decorativos indianos, reproduções de ideogramas chineses...), mas essa questão não é desenvolvida na história.

4 Em arte, procedimento de inserir, no interior de uma obra, uma representação de si mesma ou de outra obra similar, em miniatura; encaixe. 
Senti falta do odor do jasmim branco [...] o perfume de um outro tempo, a infância. Decidi, então, perambular pela cidade, dialogar com a ausência de tanto tempo [...] sentia um pouco de temor e de estranheza, e embora um abismo me separasse daquele mundo, a estranheza era mútua [...] eu não queria ser uma estranha, tendo nascido e vivido aqui. (HATOUM, 2008, p. 109)

Algo de proustiano nesse "perfume de um outro tempo" leva à deambulação física e, sobretudo, mental, pelos (des)caminhos da memória. Depois de tantos anos fora, a narradora busca lembranças de infância, sua própria história na cidade, mas se depara com "temor e estranheza": identifica que um "abismo" - uma "defasagem" segundo Leibovici (2014, p. 112) - a separa "daquele mundo": ao deixar Manaus, adotou outra cidade, outra vida, outro mundo. Trânsfuga, adquiriu outra identidade, e reconhece que "a estranheza é mútua", mulher e cidade tornadas estranhas uma à outra. $\mathrm{O}$ sentimento de não pertencimento e de perda é inevitável: "eu não queria ser uma estranha, tendo nascido e vivido aqui" - numa clara expressão do dilaceramento de que fala Bourdieu (2007). Mas é a qualidade de trânsfuga que permite à narradora o afastamento crítico necessário à realização da deambulação, pois ela decide ultrapassar o espaço da infância e se aventura pela "cidade proibida": "Crescemos ouvindo histórias macabras e sórdidas daquele bairro infanticida" escreve ao irmão, e conclui: "Foi preciso distanciarme de tudo e de todos para exorcizar essas quimeras, atravessar a ponte e alcançar o espaço que nos era vedado" (HATOUM, 2008, p. 110) - a parte mais pobre da cidade e suas expressões de pobreza. A transgressão do interdito dos tempos de criança é uma conquista mental e afetiva da mulher adulta, que porta um olhar crítico sobre as cenas deploráveis do caos urbano e da miséria humana que testemunha.

Essa narradora sem nome também é trânsfuga por estar entre duas casas, duas mães, duas realidades familiares, duas gerações da família de adoção, o passado e o presente, o Norte e o Sul, sem conseguir, poder ou querer definir-se ou optar por uma das possibilidades ou direções ao seu alcance. Essa indefinição não é necessariamente negativa nem repreensível; pode ser encarada como uma situação híbrida resultante de culturas híbridas (BHABHA, 1998, por exemplo), mundos cada vez mais (de)compostos e mesclados, incertos, quiçá pós-modernos. Sem rumo certo na vida, ${ }^{5}$ ela abraça a missão efêmera de escrever sobre

${ }^{5}$ Como a canoa sem rumo do desenho infantil que ela percebe ao entrar na casa da mãe biológica, e que "tanto destoava da decoração suntuosa que o cercava" e que fez "latejar algo em sua memória, algo que remete a uma viagem, a um salto que atravessa anos, 
Emilie, enquanto retraça a própria história, ou, nos termos de Leibovici (2014, p. 112), dá forma a "seu desejo de escritura [que] excede o simples desejo" de fazer o relato do retorno à cidade da infância, pois ela "também escreve para dar sentido à defasagem constantemente revivida entre suas disposições pessoais e a configuração das relações sociais em que ele teve que evoluir e que seu texto decifra": nas entrelinhas da história da matriarca e da família, a narradora forja para si um Norte, um senso de sentido e orientação, e o leitor desvenda seus dramas intrínsecos, seu entorno e a sociedade em que se insere.

Como a narradora inominada, outros personagens tentam escapar desses dramas ou sinas familiares, constituindo-se em trânsfugas em sua recusa, incapacidade ou impossibilidade de permanecerem no núcleo de origem. Nesse sentido, um grande trânsfuga dessa trama, no sentido de quem renega o núcleo familiar e o deserta, é Hakim, o primogênito, que, em conversa com a narradora, assim explica os modos de ser dentro do casarão, e sua recusa da estrutura de poder da família:

Alguns [moradores pobres da Cidade Flutuante] passaram a frequentar o sobrado para pedir conselhos a Emilie e, eventualmente, esmolas e favores. Muito antes de eu viajar [...] ela já distribuía alimentos aos filhos da lavadeira Anastácia Socorro. Eu procurava ver nesse gesto uma atitude generosa e espontânea da parte de Emilie; talvez existisse alguma espontaneidade, mas quanto à generosidade... devo dizer que as lavadeiras e empregadas da casa não recebiam um tostão para trabalhar, procedimento corriqueiro aqui no norte. Mas a generosidade revela-se ou se esconde no trato com o Outro, na aceitação ou recusa do Outro. [...] Eu presenciava tudo calado, moído de dor na consciência, ao perceber que os fâmulos não comiam a mesma comida da família, e escondiam-se nas edículas ao lado dos galinheiros, nas horas da refeição. A humilhação os transtornava até quando levavam a colher de latão à boca. Além disso, meus irmãos abusavam como podiam das empregadas, que às vezes entravam num dia $\mathrm{e}$ saiam no outro, marcadas pela violência física e moral. [...] Vozes ríspidas, injúrias e bofetadas também participavam deste teatro cruel no interior do sobrado. Lembro de uma cena que me deixou constrangido e apressou a minha decisão de partir, e assim venerar Emilie de longe. (HATOUM, 2008, p. 76)

décadas" (HATOUM, 2008, p. 8) - numa imagem alegórica do que estaria por vir ou ser explicado ao longo do livro. A descrição desse quadro está em nota mais adiante. 
O primogênito, então, renega o "teatro cruel no interior do sobrado", os abusos praticados por Emilie e seus outros filhos contra agregados e criadagem, reinando absolutos, mandando, desmandando e incorporando a brutalidade (pós-colonial) aos hábitos da casa - que representa, em miniatura, o Brasil e suas contradições. E Hakim deixa a casa onde se sente uma voz e um olhar destoantes, sabendo-se figurante nesse "teatro cruel". Acaba indo viver num país oriental, possivelmente o Irã, numa trajetória de imigração não explicada ao leitor, mas que faz dele, talvez, um adepto da aventura da imigração por terras exóticas e distantes, um trânsfuga cultural (pois não retorna às raízes levantinas da família). De qualquer forma, expatria-se, tornando-se sobretudo um trânsfuga em situação de imigração - reproduzindo, inversamente, o movimento migratório dos pais (HATOUM, 2008, p. 76).

A crítica à violência doméstica amplamente aceita (no Norte, segundo o personagem, mas também no resto do Brasil) será ecoada no romance seguinte. Em Dois irmãos, o narrador Nael fala do mesmo tipo de exploração dos serviçais, só que dando-lhe primazia entre os temas tratados, pois a maior vítima dessa violência, nesse romance, é sua mãe, a criada Domingas, agregada que habita os fundos do casarão de Zana e sua família: Domingas vivia

cansada, derrotada, entregue ao feitiço da família, não muito diferente das outras empregadas da vizinhança, alfabetizadas, educadas pelas religiosas das missões, mas todas vivendo nos fundos da casa (HATOUM, 2000, p. 67). ${ }^{6}$

Domingas gostava de Yaqub, o filho primogênito dos donos da casa, mas será estuprada por seu gêmeo Omar, e ninguém sabe ao certo - nem Domingas, nem Nael, nem o leitor - qual dos gêmeos é o pai do narrador. Nesse drama vivido entre casa grande e senzala, Nael passa parte da vida sem saber quem é seu pai, para, em seguida, esperar ser filho do gêmeo amigo Yaqub, até descobrir o estupro cometido pelo gêmeo temido Omar.

Assim, diferentemente da narradora do Relato, que, mesmo adotada e incorporada à família, é estranha a muitos dos dramas que relata (a chegada da primeira geração de imigrantes etc.) e mantém, quanto a

\footnotetext{
6 A semelhança entre as práticas de violência no interior dos sobrados do Relato e de Dois Irmãos é um dos vários indícios da forte identidade entre as duas matriarcas de origem levantina; há, inclusive, menção, em Dois Irmãos, a uma Emilie, amiga idosa com quem Zana conversa em árabe.
} 
estes, uma perspectiva distanciada, Nael encontra-se no cerne do enredo e participa dos dilaceramentos que lhe são intrínsecos.

Como o romance anterior, a história de Dois irmãos é contada em vaivém cronológico, tendo por preâmbulo o relato da morte da matriarca, para em seguida, no primeiro capítulo, voltar no tempo, para o momento do retorno do adolescente Yaqub de seu "exílio" no Líbano. O livro termina com o último encontro do narrador com um Omar de meia-idade e envelhecido, depois de seu "exílio" na prisão, que surge inadvertidamente, em noite de temporal, para fantasmagórica visitação à casa da infância e ao narrador. Também como no romance anterior, nas últimas páginas do texto, o narrador fala sobre seu trabalho de escritura recém-começado.

Com relação ao drama da filiação, de tanto testemunhar o ódio entre os dois irmãos, e a destruição da casa que lhe foi decorrente, Nael, depois de vivenciar o dilaceramento da dúvida e de outras rupturas, acabou renegando ambos os possíveis pais:

a vontade de me distanciar dos dois irmãos foi muito mais forte do que [as boas] lembranças. A loucura da paixão de Omar, suas atitudes desmesuradas contra tudo e todos neste mundo não foram menos danosas do que os projetos de Yaqub: o perigo e a sordidez de sua ambição calculada [...] Hoje penso: sou e não sou filho de Yaqub [...] O que Halim [o avô] havia desejado com tanto ardor, os dois irmãos realizaram: nenhum teve filhos (HATOUM, 2000, p. 263-264).

O narrador rejeita, então, qualquer sonho de filiação, pois ambos são criaturas excessivas em suas maneiras de ser e em seu ódio recíproco. Nael não quer sentir-se continuidade ou filho de nenhum deles, contentandose com a identificação maior com o avô, Halim, que tem pelo menino verdadeira afeição. Em certa ocasião, Nael e Omar, o problemático gêmeo caçula, ficam doentes ao mesmo tempo, e o narrador alegra-se ao "saber que Halim dera mais atenção ao neto bastardo que ao filho legítimo" (HATOUM, 2000, p. 200) - o que mostra que a questão da bastardia e da linhagem legítima possuem para esse patriarca polaridades invertidas.

Aliás, Halim, patriarca excepcional, admite que nunca desejou progenitura, e chega a reclamar com a esposa quando esta traz, do orfanato, a índia Domingas - que seria criada dentro da casa para tornarse empregada agregada à família. Halim considerava "penoso criar o filho dos outros, um filho de ninguém" (HATOUM, 2000, p. 250) - sem qualquer sinal de dó pelos desvalidos. Anos depois, quando Domingas 
dá à luz seu neto, porém, Zana lhe pergunta, irônica: "E agora, vamos aturar mais um filho de ninguém? Halim se aborreceu, disse que tu [Nael] eras alguém, filho da casa" (HATOUM, 2000, p. 250). A passagem de "filho de ninguém" para "alguém filho da casa" é a aceitação da bastardia por esse patriarca que não se sente continuado nos filhos. Halim vai ao batizado do menino e pede que ele tenha o nome de seu pai.

Nael, então, mais que os gêmeos, carrega a linhagem de Halim, recebendo o nome do ancestral e a confiança do avô: "Eu era o seu confidente, bem ou mal era um membro da família, o neto de Halim”, e essas confidências, múltiplas, esparsas e fragmentárias serão preciosas para o narrador, que "juntava os cacos dispersos, tentando recompor a tela do passado" (HATOUM, 2000, p. 134). Caberá ao neto escrever, se não a história da família (que é a narrativa do romance), as histórias e "causos" do avô, enquanto projeto de escritura anunciado nas últimas linhas do livro:

Eu tinha começado a reunir, pela primeira vez, os escritos de Antenor Laval [poeta e professor de francês], e a anotar minhas conversas com Halim [...]. Ia de um a outro, e essa alternância - o jogo de lembranças e esquecimentos - me dava prazer (HATOUM, 2000, p. 265).

Essa narrativa não corresponde ao livro que o leitor tem nas mãos, onde os escritos de Laval são apenas mencionados e Halim não é a única fonte de informações do narrador. Essa escritura prazerosa é, entretanto, como que o "perseverar no ser" de que fala Bourdieu (2007), na efetivação da transmissão das histórias (da vida) do avô para o neto, numa linhagem refeita, recriada, depois de desvios e despautérios (a violência perpetrada contra a mãe e a incógnita da paternidade), sanando uma série de dilaceramentos vividos pelo narrador.

No final do livro, Nael já não é mais o filho da empregada e neto bastardo, mas proprietário de sua casinhola nos fundos do casarão - "A área que me coube, pequena [...] é este quadrado no quintal. 'Tua herança', murmurou [a tia] Rânia" (HATOUM, 2000, p. 256). A explicitação da palavra "herança" é de monta e representa a "perseverança no ser" e a materialização dessa perseverança no universo narrado. Único herdeiro, ironicamente, do que restou do patrimônio da família, e único perpetuador da memória desse núcleo familiar, ao aceitar essa herança, paradoxalmente, Nael é um trânsfuga que supera a pobreza e a bastardia, e se estabelece como professor e futuro escritor. 
Outro trânsfuga de Dois irmãos é o gêmeo mais velho, Yaqub, que tem uma história complexa com a imigração e uma situação estorvante dentro da família. Preterido em prol do caçula depois de uma rixa violenta ainda na infância, que lhe gera uma cicatriz na face e outra ferida: Yaqub é enviado pelos pais ao Líbano, à terra do pai, para junto de sua família, onde vive como pastor alguns anos. Odiou a experiência de ser estrangeiro na terra natal do pai, verdadeira contra-aventura desproposital e, para ele, incompreensível. Já adulto, relembra: "Não morei no Líbano [...] Me mandaram para uma aldeia do sul, e o tempo que passei lá, esqueci" (HATOUM, 2000, p. 118-119). Não esqueceu e não perdoou, culpou os pais por esse exílio nunca explicado (a ele), e não se reconciliou com o caçula, que passou a agir como intragável filho único. Ao terminar a escola, um professor o aconselha a deixar a cidade: "Se ficares aqui, serás derrotado pela província e devorado pelo teu irmão" (HATOUM, 2000 , p. 41). Yaqub arquiteta, então, um plano, e parte para São Paulo (numa migração voluntária e premeditada), se forma engenheiro e casa com a moça que gerou a rixa de infầncia com o irmão. Anos mais tarde, profissional renomado, finge que ajuda o gêmeo nos negócios, mas arma-lhe uma cilada, leva-o ao fracasso e, com isso, à ruína da família, à venda do sobrado, e ao fim melancólico de uma história.

Esse trânsfuga não só deserta o espaço familiar como o destrói, numa rejeição radical do passado e da estrutura familiar e afetiva onde se sentiu excluído ou preterido desde a infância. Aniquilou a casa em que se sentiu estranho e estrangeiro, rompeu definitivamente os elos, abandonou quem amou o irmão, "devorou" o irmão (denunciou-o à polícia política da ditadura militar). Adquire contornos de um trânsfugaogro, obcecado pela rixa e pela ferida da infância, pela fratura do exílio, numa recusa obstinada em cicatrizar e/ou perdoar. Vingou-se, em suma, mas garantiu a herança material do possível filho, providenciando o legado da casinhola nos fundos do quintal. Esse legado pode dever-se a um sentimento de justiça e retribuição ao jovem e sua mãe, Domingas, que escaparam à sua sanha ressentida, ou a uma tentativa (frustrada) de forjar laços de parentesco, se não de filiação.

\section{Contraditores da herança e da linhagem}

Nos três romances, o tempo entre a vivência dos últimos fatos narrados (em termos cronológicos) e sua escritura é longo e refletido. No Relato, a narradora leva "quase vinte anos" para voltar a Manaus e realizar encontros e rememorações que permitem o que Leibovici (2014, p. 112) define como a "compreensão e exposição de si", ou seja, o retorno 
à terra natal e as rememorações que lhe são consequentes, e seu relato, que transmite ao irmão e ao leitor (cuja escritura, porém, é imediata). Em Dois irmãos, o narrador passa "mais de vinte anos" para escrever o livro, que não corresponde às anotações mencionadas nas últimas páginas, mas constitui, novamente citando Leibovici (2014, p. 112), um instrumento que confere "sentido à defasagem constantemente revivida entre as disposições pessoais" do narrador e seu entorno. Em Cinzas do Norte, o narrador leva "muito tempo" para contar a história de seu amigo Mundo, como lhe instara o tio Ran - respeitando a memória do amigo, mas não a urgência do tio.

O narrador de Cinzas do Norte é Lavo (Olavo), órfão criado pelos tios pobres, que conta a história de sua família e a da família de Mundo (Raimundo), herdeiro de grande fortuna e foco da trama. Começa a redigir seu livro ainda durante os acontecimentos narrados, como explica no penúltimo capítulo: seu tio Ran (Ranulfo), que escrevia, segundo suas próprias palavras, "o relato sobre Mundo", "histórias de Mundo e do meu amor, Alícia [mãe de Mundo]", verdadeira "mixórdia escrita a lápis" (HATOUM, 2005, p. 302), suspeita que ele, Lavo, também estivesse escrevendo um livro sobre o amigo. "[ele] queria que isso fosse verdade, pois só assim leria a última carta de Mundo" (HATOUM, 2005, p. 303), onde é revelado um grande segredo. Vários segredos e mistérios serão desvendados progressivamente no vaivém entre as diferentes fontes de que se serve Lavo para contar sua história.

O livro de Lavo se compõe, então, de sua narrativa (resultante de sua observação pessoal e dos aportes de seus interlocutores) intercalada de capítulos em itálico - o manuscrito escrito pelo tio, na primeira pessoa, na forma de uma série de depoimentos íntimos dirigidos ao rapaz morto -, cartas de Mundo enviadas a Lavo do autoexílio no Rio e na Europa, acrescidas, à guisa de último capítulo, da surpreendente e derradeira carta de Mundo, "rabiscada" em seu leito de morte, sobre seu fim de vida, suas considerações sobre a arte e a revelação súbita, feita pela mãe diante de sua morte iminente, da verdadeira identidade de seu pai. Em sua carta, Mundo fala da dificuldade de escrever: "pensei em reescrever minha vida de trás para frente, de ponta-cabeça, mas não posso, mal consigo rabiscar" (HATOUM, 2005, p. 303). O livro de Lavo começa com citações dessa carta, às quais acrescenta:

na margem da última página, estas palavras: 'meia-noite e pouco'. Talvez tenha morrido naquela madrugada, mas eu não quis saber [...]: detalhes não interessam. Uns vinte anos depois, a história de Mundo me vem à memória com a força de um fogo escondido pela infância e pela juventude (HATOUM, 2005, p. 9-10). 
Essa circularidade entre excipit e incipit reforça a importância da carta reveladora: o preâmbulo do livro retrata a leitura da carta, em Copacabana, depois da morte do herói, e o primeiro capítulo volta no tempo, com a imagem do pai de Mundo, Jano (Trajano Mattoso) e seu cão Fogo, pelas ruas de Manaus. A insistência sobre a dificuldade de escrever, como no Relato, aponta para uma narrativa meta-literária, onde o processo artístico e criativo é particularmente relevante na elaboração da trama. Como os narradores dos romances anteriores, a história nodal (a trajetória de Mundo) será estreitamente tecida e enfronhada a outras, dos demais personagens, alguns dos quais são fontes orais de informação desse narrador que aos poucos preenche lacunas, descobre detalhes e mistérios, e revela-os ao leitor numa oscilação cronológica característica da escritura de Hatoum.

O primeiro contato do narrador com o herói é episódico, um encontro casual em uma praça, em que Mundo the dá de presente o desenho da estátua de um navio (que adorna a praça):

Um barquinho torto e esquisito no meio de um mar escuro que podia ser o rio Negro ou o Amazonas. Além do mar, uma faixa branca [...] Foi o primeiro desenho que ganhei dele: um barco adernado, rumando para um espaço vazio (HATOUM, 2005, p. 12).

Que lembra um desenho mencionado na segunda página do Relato, outro barquinho sem rumo desenhado por uma criança, possivelmente a narradora, também ela, como Mundo, de horizonte pessoal incerto, à deriva na $\operatorname{vida}^{7}$ (o personagem largado "à deriva" de Dois irmãos é o gêmeo Omar - expressão usada para caracterizar seu olhar fixo mas obnubilado, nas últimas linhas do livro).

Mais tarde, frequentam a mesma escola, e a amizade entre os meninos será duradoura e constante. Já nesse momento, ainda na infância, Mundo é um estranho, seja em casa ou no colégio, por causa de seu talento artístico.

Jano, filho de portugueses que enriqueceram no Brasil, deseja que o filho o suceda nos negócios da família, frequente a elite local e seja

\footnotetext{
7 Num canto da parede da sala da casa da mãe, a narradora percebe "um pedaço de papel" que "parecia o rabisco de uma criança" onde "duas manchas de cores eram formadas por mil estrias, como minúsculos afluentes de duas faixas de águas de distintos matizes; uma figura franzina, composta de poucos traços, remava numa canoa que bem podia estar dentro ou fora d'água. Incerto também parecia o seu rumo, porque nada no desenho dava sentido ao movimento da canoa. E o continente ou o horizonte pareciam estar fora do quadrado do papel" (HATOUM, 2008, p. 8).
} 
bom aluno. Mundo gosta de desenhar, conviver com as crianças pobres e correr pela chuva. Então, seja por zelo da mãe ou punição do pai, o menino vive trancado no porão do palacete, desenhando. Um dia, quebra a janela do porão e foge para mostrar um desenho ao pai; o menino se fere na mão - o que cria uma cicatriz (cuja origem o próprio jovem esquece, e sua mãe não quer explicar); o pai permanece insensível ao talento do menino, sonhando para ele outros pendores e valores.

Em diversos momentos do texto, essa ferida inicial, que é também moral e afetiva, será evidenciada e amplificada. Por exemplo, diante dos objetos no quarto do filho, Jano diz a Lavo: "Nenhum livro de matemática nas estantes. Só arte, poesia... Pior ainda: nenhuma fotografia de mulher, a não ser da mãe. Meu filho não pode continuar assim" (HATOUM, 2005, p. 33); ou quando Mundo reclama do pai: "[ele] não pensa que o filho pode ser diferente dele" (HATOUM, 2005, p. 64), e "um pai não pode gostar mais de um cachorro do que de um filho" (HATOUM, 2005, p. 123) - diz o jovem ressentido com o entrosamento entre Jano e Fogo; ou ainda: "hoje, [meu pai] faz quarenta anos, mas deve comemorar só o tempo que viveu sem o filho" (HATOUM, 2005, p. 45) - plenamente consciente e amargurado com a rejeição paterna. Um dos observadores do ressentimento crescente entre pai e filho é Macau, o motorista: "Pai e filho sempre tiveram a alma danada [...] Um pai torto: nunca pôs a criança nos braços. Tinha uma birra esquisita com o Raimundinho." (HATOUM, 2005, p. 275).

Em Dois irmãos, a rixa entre Yaqub e Omar é um fado; segundo Domingas, "nasceram perdidos" (HATOUM, 2000, p. 237), condenados ao ódio mútuo pelo mito. Como a cicatriz no rosto de Yaqub, que registra o momento crucial em que o ódio entre os gêmeos é como que selado, a cicatriz na mão de Mundo (que não será valorizada na trama) sela a diferença, imperdoável para Jano, entre filho e pai. Diferença que o pai suspeita, o narrador sugere e o leitor conclui, e que tem a ver com a verdadeira identidade do pai do menino.

Também na escola a arte de Mundo lhe cria problemas. Corpos caídos, "primeira sequência" de desenhos do futuro artista, é vista - com maus olhos - pelos colegas retratados:

Vimos nossos corpos tombados, nossos rostos fazendo caretas medonhas: [um], meio monstruoso e o único sem cabeça, [outro,] com cara de gafanhoto, e o professor, no centro da quadra, um arlequim atarracado, a cabeça separada do corpo. Os desenhos distorciam e misturavam nossos corpos, reconhecíamos traços de nós mesmos e dos outros, de modo que todos se sentiram ultrajados" (HATOUM, 2005, p. 17-18). 
Primeira obra vista pela coletividade e primeira punição social: em resposta às caricaturas e às distorções monstruosas, Mundo será humilhado publicamente: colam-lhe uma rabiola nas costas, ateiam fogo e riem quando o menino se joga no lago da praça. $O$ menino não reagiu, e comentou com o amigo que "estava acostumado", referindose à constante rejeição do pai no interior do casarão. Exclusão e incompreensão universal de Mundo e sua arte; ele não se enquadra e não se esforça para fazê-lo, trânsfuga que se assume diverso.

O "fogo", então, é uma presença recorrente na trama, desde o título, que fala em "cinzas", passando pelo "fogo escondido", que representa, para o narrador, a lembrança da história de Mundo, assim como se manifesta no cão de Jano, fiel companheiro do rico empresário, "seu tesouro", espécie de filho substituto ou duplo do dono. Também fará parte da primeira obra adulta de Mundo, Campo das cruzes, grande projeto que denuncia "a paisagem calcinada: a floresta devastada ao norte de Manaus" (HATOUM, 2005, p. 148) - as "cinzas do norte" -, e o "crime urbano" que representa o condomínio do Novo Eldorado, empreendimento mal realizado por agentes do governo militar; a obra inclui uma performance dos moradores, em que se queimam oitenta cruzes e se critica o regime. Em retaliação, o pai, que tem amigos no comando do governo local, junta todos os pertences, desenhos e quadros do filho, e os incinera numa fogueira armada no quintal. O rompimento definitivo entre os dois é selado por fogo e cinzas em ambos os campos da guerra entre pai e filho.

Entre o nascimento feliz e o incêndio das obras de arte do filho, Jano passa por um longo processo de frustração e decepção. Ran explica a Mundo:

[Alícia] me disse que Jano estava feliz por ter um herdeiro Mattoso, um homem, e não falava em outra coisa, e depois tua mãe percebeu que ele estava envaidecido não com o filho, mas com o herdeiro, até que um dia brigaram por causa da palavra herdeiro, que ela não aguentava mais ouvir... Jano disse: "É o que meu pai mais queria, um neto... um herdeiro [...]" [Eu e tua mãe namorávamos no cinema...] enquanto teu pai trabalhava para o herdeiro. E logo que ele chegava em casa e perguntava: "Onde está o herdeiro?", tua mãe dizia: "Nosso filho tem nome" (HATOUM, 2005, p. 216, grifo do autor). 
Talvez suspeitando não ser o pai do menino, Jano assumiu, mesmo assim, a ideia de fazer dele o herdeiro da família portuguesa empreendedora e seu continuador. O pai de Jano era um imigrante português pobre que fez fortuna em Manaus: "Ele veio de Portugal sem um tostão no bolso. Só coragem e vontade de ser alguém. Um homem religioso que acreditava na civilização, no progresso" (HATOUM, 2005, p. 35). Esse espírito empreendedor também será descrito no Relato: "a sanha e a determinação dos que desembarcam jovens e pobres para no fim de uma vida atormentada ostentarem um império" (HATOUM, 2008, p. 56). E o pai de Jano, de fato, ergue um império, que o filho pretende ampliar e legar à sua descendência como parte de um projeto familiar com ambições civilizatórias, numa lógica que reproduz padrões arcaicos de colonização.

A palavra "herdeiro" é colocada em destaque no texto, e sua diferença com relação a "filho" é ressaltada pela mãe, mas Jano não faz distinção: "Se eu tivesse outros filhos! Por isso invejo a sorte de alguns proprietários da região, homens e mulheres que criaram homens e têm herdeiros. Enquanto eu vou morrer sem herdeiro, Deus não me deu um" (HATOUM, 2005, p. 87) - o filho cada vez mais distante do pai não se assume herdeiro. A certa altura, depois de nova decepção, resume: "[Mundo] não herdou uma gota do meu sangue" (HATOUM, 2005, p. 88) - seja como força de expressão ou clarividência.

Mundo será, então, um grande trânsfuga que rejeita, como a mãe, a noção de herdeiro, contesta o pai politicamente, critica seus feitos comerciais, abandona a casa, as escolas, sabota o projeto do pai, para ele, de formatura e profissionalização, refugia-se num bairro pobre da periferia, escapa com a ajuda da mãe para o Rio, e, de lá, para a Europa, onde, rebeldia máxima contra os ditames do patriarca, vive (mal) de seu trabalho como artista. Dentre os personagens de Hatoum (no corpus estabelecido aqui), Mundo será o maior contraditor da herança paterna: responde rejeição com rejeição, ódio com ódio, fogo com fogo, até depois da morte do pai, realizando uma obra, História de uma decomposição - Memórias de um filho querido, que ele assim explica a Lavo em sua carta final:

Em Londres me concentrei nos sete quadros-objetos, era um modo de me libertar. A imagem de Jano não ficou isolada na minha cabeça, era o processo que interessava, a vida pensada, a vida vivida, dilacerada $[\ldots]$ Formas mais ou menos figurativas, decompondo o retrato da família, até chegar à roupa e aos dejetos de Jano. Ideias e emoções que nos movem. Me livrei de um peso quando terminei esse trabalho, mas não me considero um artista, Lavo. Só quis dar algum sentido a minha vida. (HATOUM, 2005, p. 307, grifo nosso). 
Mundo cria algo novo e instigante a partir de resíduos - como que cinzas - do pai, voltando a elaborar, como nas caricaturas dos colegas da escola, deformações monstruosas. Dá forma a ideias e emoções - emoções também monstruosas, intensas -, assim como dá "algum sentido à sua vida" - formas que, como no caso do narrador analisado por Leibovici (2014, p. 112), produz sua arte "para dar sentido à defasagem constantemente revivida", a ferida repetidamente aberta pela lembrança dilacerante da rejeição do pai. $\mathrm{O}$ artista representa, expressa e exorciza o peso dessa história e a ironia dramática do "filho querido", menos amado que o cão.

Mundo também será trânsfuga ao deixar Manaus, migrar para o Rio, e, depois, emigrar para a Europa. A epígrafe do livro já anuncia esse contexto trânsfuga: "Eu sou donde eu nasci. Sou de outros lugares (João Guimarães Rosa)" (HATOUM, 2005) - o rebelde e cosmopolita Mundo aspira, de fato, à amplidão de seu apelido. Na Europa, ele conhece a brasileira Mona e, através dela, toda a uma comunidade de estrangeiros que se agrega e solidariza em Londres. Sobre essa amiga que o acolhe, ele diz: "desconfia até da própria sombra, e tem um olhar melancólico e autoirônico dos para sempre expatriados" (HATOUM, 2005, p. 244). Esse entendimento entristecido da vida do autoexílio desconstrói qualquer glamour inicialmente vislumbrado na vida nas grandes capitais europeias. O imigrante pobre, como é o artista principiante, enfrenta toda sorte de percalços, pena com a solidão e se dilacera entre desejos antagônicos de persistir no sonho e de sucumbir à saudade e ao (re)conforto da terra natal e da família.

Sobre sua vivência no exterior, Mundo avalia:

Um desconhecido, doente e estrangeiro. Mais um artista no desterro [...]. Não queria perambular para sempre... morrer sufocado em terra estrangeira. A errância não era o meu destino, mas a volta ao lugar de origem era impossível" (HATOUM, 2005, p. 308).

Está claro que o herói não tem a sanha do imigrante empreendedor, e não encara a imigração como uma aventura, mas como uma atribulação. Interessava-lhe a arte, mas a doença o abate e o obriga a voltar, não ao lugar de origem ("impossível", terra do pai, onde deveria ter sido herdeiro), mas ao Rio de Janeiro, onde a mãe se instala depois da morte de Jano.

Mundo termina sua derradeira carta e o livro de Lavo: "O que restou de tudo isso? Um amigo, distante, no outro lado do Brasil. Não posso mais falar nem escrever. Amigo... sou menos que uma voz..." (HATOUM, 2005, p. 311). Essa frase final da despedida de Mundo reúne ecos de narrativas passadas: "um amigo distante no outro lado do Brasil" lembra a descrição 
do adulto próspero e promissor Yaqub, que subia na vida em São Paulo, "usando a máscara do que havia de mais moderno no outro lado do Brasil" (HATOUM, 2000, p. 61) - num possível entendimento de que Lavo, ao se tornar advogado de carreira, ascendia (como Yaqub, reproduzindo o modelo da ascensão social rejeitada por Mundo); o outro eco de um livro passado é a referência a ser "menos que uma voz", remetendo ao Relato e à necessidade da narradora de "recorrer à própria voz" que unificaria as demais, em seu mosaico de narrações (HATOUM, 2008, p. 148) - em situações opostas: ele, moribundo, ela, sobrevivente.

Já Lavo nunca quis sair de onde nasceu:

Mundo sabia que dificilmente eu sairia de Manaus; nas cartas que lhe enviei, insisti nesse assunto, dizendo que minha cidade era minha sina, que eu tinha medo de ir embora, e mais forte que o medo era o desejo de ficar, ilhado, enredado na rotina de um trabalho sem ambição" (HATOUM, 2005, p. 269).

Medroso e modesto, revela ao leitor suas conquistas, por vezes, de maneira elíptica. Jano comenta: "Li teu nome na lista de calouros da faculdade de direito. Alícia vai se orgulhar do amigo do filho" (HATOUM, 2005, p. 91). E é ela quem diz a Lavo, sobre Mundo: "Ele te admira, Lavo. Um órfão criado por uma tia pobre... Vai ser advogado, e pode vir a ser juiz, doutor" (HATOUM, 2005, p.193), e pede que Lavo converse com o filho rebelde, pois "as palavras de um órfão valem mais" que as suas, numa inversão radical da expectativa inicial (o órfão fadado irremediavelmente a diferentes formas de exclusão). O narrador, então, revela ser, também ele, duplamente trânsfuga, pois, deixa para trás a situação econômica precária da infância - o que já o torna um "trânsfuga de classe"-, mas escapando ao modelo convencional da busca de uma ascensão social desenfreada: um "trabalho sem ambição", um homem cuja ambição é advogar "em defesa de detentos miseráveis esquecidos nos cárceres" (HATOUM, 2005, p. 285) - outro tipo de ambição.

Aliás, a trajetória dos amigos tem o movimento de uma gangorra: nascidos na mesma época, no momento em que ocorriam os festejos faustosos do primeiro aniversário do "herdeiro", os pais de Lavo morriam num naufrágio. Enquanto Jano dizia a todos que Mundo seria "o maior exportador da região" (HATOUM, 2005, p. 217), Lavo era acolhido por Ramira, costureira modesta, e Ranulfo, sem profissão definida. As expectativas, com o tempo, se invertem, o órfão progride e o herdeiro se perde. Cada qual trânsfuga à sua maneira, driblando expectativas e sonhos alheios, encontram seu lugar, seja para morrer (no caso de Mundo) ou para "perseverar no ser", sobreviver (no de Lavo). 


\section{Concluindo. Caminhos sobre cinzas}

Nenhum dos personagens mencionados tem filhos, ou dá sinal de desejar iniciar sua própria família, alguma nova linhagem. Parecem todos descrentes do futuro - "essa falácia que persiste" chega a dizer Nael (HATOUM, 2000, p. 263), atendo-se ao passado e sua rememoração melancólica.

Ao lado dos grandes contraditores da herança, que traem as expectativas do núcleo familiar (o qual desertam, descontinuam e/ou destroem), há os narradores, testemunhas da ruína da casa, órfãos ou bastardos excluídos por princípio da família e que, por isso mesmo, sobrevivem à sua ruína. Estes não só sobrevivem, como descortinam caminhos pessoais inauditos, contrariando e desviando-se da sina prevista: reescrevem o destino traçado pela doxa e escrevem livros, onde deixam de ser figurantes de histórias alheias para tornarem-se seus tecelões, artífices ou arquitetos - protagonistas do fazer criativo.

No Relato, o sobrado decai e se esvazia; em Dois irmãos, é desmembrado e vendido; em Cinzas do Norte, é simplesmente demolido. Numa progressão crescente da degradação, são verdadeiras "Casas de Usher", cuja queda fatídica decorre de uma corrupção intrínseca (no caso do conto de Poe, o incesto entre os irmãos, causa ou efeito do fim da linhagem - origem, talvez, da recorrente sugestão de incesto nesses romances de Hatoum). Todas essas quedas são enredos dinâmicos em que a destruição cede lugar à criação (a ruína da casa gera seu relato), inscrevendo, em linha d'água, o movimento da Fênix renascida das cinzas pelo ato de recordar fatos e personagens, devolvendo-lhes vida e alma.

Essas cinzas, sinal da destruição de outrem, são o próprio solo onde caminham os narradores, base de suas reflexões e questionamentos. Sobre os restos da casa caída eles traçam e tramam os rastros da própria existência que, do ponto de vista dos patriarcas, é marginal, mas que, ao se assumirem trânsfugas-testemunhas, angariam para si a primazia, a autoria, escrevem a história e dela se apropriam.

Concluímos com a poética descrição da queda da casa do Relato, quando morre a matriarca:

O pânico e a aflição diante da morte, a casa varrida por um vendaval, um tremor de terra no coração da família, não se sabe a quem recorrer nesta manhã que parece fora do tempo, nesta casa em ruínas, às avessas, e onde as preces se misturam com as confissões de culpa. (HATOUM, 2008, p. 124) 


\section{Referências}

BHABHA, Homi K. O local da cultura. Tradução de Myriam Ávila, Eliana Lourenço de Lima Reis, e Gláucia Renate Gonçalves. Belo Horizonte: Editora UFMG, 1998.

BOURDIEU, Pierre. As contradições da herança. In: NOGUEIRA, Maria Alice; CATANI, Afrânio (orgs.). Pierre Bourdieu. Escritos de educação. Petrópolis: Editora Vozes, 2007. p. 231-237.

HATOUM, Milton. Cinzas do Norte. São Paulo: Companhia das Letras, 2005.

HATOUM, Milton. Dois irmãos. São Paulo: Companhia das Letras, 2000.

HATOUM, Milton. Relato de um certo Oriente. São Paulo: Companhia das Letras, 2008.

LEIBOVICI, Martine. De Ricœur à Foucault: en finir avec l'herméneutique de soi? Quand transfuges et parias racontent leur vie. Tumultes, Liège ; Paris, n. 43, p. 107-121, 2014. Disponível em: https://www.cairn.info/ revue-tumultes-2014-2-page-107.htm\#no5. Acesso em: 24 jun. 2020.

MILTON Hatoum - Conexões Itaú Cultural (2009) - Parte 1/4. [S. l.: s. n.], 2009. 1 vídeo (3 min.) Publicado pelo canal Itaú Cultural. Disponível em: https://www.youtube.com/watch?v=g9EwHRY9pm4\&feature=emb_rel_ end. Acesso: em 23 jun. 2020.

Recebido em: 17 de julho de 2020.

Aprovado em: 30 de abril de 2021. 